\title{
ENTREVISTA À HOPE OLSON (31/08/2018)
}

\author{
Entrevistada: Hope Olson* \\ Daniel Martinez-Ávila** \\ Rosali Fernandez de Souza ${ }^{* * *}$ \\ Gustavo Silva Saldanha*** \\ Luana Sales ${ }^{* * * * *}$
}

\section{GENERAL CONSIDERATIONS}

Thank you for this opportunity to discuss (or pontificate on) issues that I have spent my career discovering, understanding, critiquing, and advocating change in various contexts. I have developed an epistemic foundation that serves as a basis for my perspective. The assumptions under which I operate are:

- I am skeptical of universal applications;

- I doubt the validity of universal one-size-fits-all goals;

- I mistrust pre-defined values; and

- I am suspicious of findings that are overly uniform.

It boils down to "question everything." Questioning and critiquing are not the same as rejecting and criticizing. Given the power of classification and other instruments of knowledge organization (KO), I believe that researchers have a responsibility to reveal what is behind/beneath our practices.

\footnotetext{
* Professor Emerita. Ph.D., University of Wisconsin-Madison, School of Library and Information Studies, 1996. M.L.S., University of Toronto ,1974. B.A., Gustavus Adolphus College, St. Peter, MN, 1972. E-mail: hopeaolson@gmail.com

** Doutor em Documentação. Professor Assistente Doutor da Universidade Estadual Paulista (Unesp). Endereço: Av. Hygino Muzzi Filho, 737 - Cx.P. 181 - Campus Universitário - CEP 17525-900 - Marília - SP. Telefone: (14) 3402-1336. Email: martinez.avila@unesp.br.

*** Doutora em Ciência da Informação. Pesquisadora Titular do Instituto Brasileiro de Informação em Ciência e Tecnologia. Endereço: IBICT, Rua Lauro Muller 455, $4^{\circ}$ andar, Botofogo, CEP 22290-160, Rio de Janeiro, RJ. Telefone (21) 3873-9468. E-mail: rosali@ibict.br

**** Doutor em Ciência da Informação. Pesquisador Associado do Instituto Brasileiro de Informação em Ciência e Tecnologia (IBICT); Professor Adjunto da Universidade Federal do Estado do Rio de Janeiro (UNIRIO). Endereço: Rua Lauro Muller, 455, sala 401, Botafogo - CEP 2290160 Rio de Janeiro - RJ. Telefone: 21 38739453. Email: gustavosaldanha@ibict.br

***** Doutor em Ciência da Informação. Professora Permanente do Programa de Pós-graduação em Ciência da Informação do convênio IBICT-UFRJ. Endereço: Rua Lauro Muller, 455, 40 andar, sala 408, CEP: 22.290-160. Telefone: (21) 97112-7411 / + 55 (21) 3873-9450.Email:luanasales@ibict.br
} 


\section{What is the epistemological relevance of the concept of culture for knowledge organization?}

As I have demonstrated in Olson 1999 and 2007 our standards for knowledge organization (KO) are derived from an Aristotelian logic that is pervaded by three characteristics: 1) mutually exclusive classes, that is there is no overlap between categories; 2) classes are arranged in a sequence that leads to a goal, I call this "teleology"; and 3) the sequences are built into hierarchies and hierarchical relationships are privileged over other characteristics. These characteristics seem intuitive when viewed from within a dominant culture, but appear different from the margins of a culture.

KO allows for exchange and analysis of connections between a limitless number of just about anything - from planets to coffee beans to snowflakes to hotel rooms to hurricanes. We now have OCLC, a digital behemoth, holding millions of surrogates (bibliographic and authority records) to download into library catalogs worldwide. The bulk of the records are from the US with a significant dollop from Europe, Canada, and so forth. They are constructed using a range of standards for record structure and elements required for dominant model's success. We create authority files, standards for creation of surrogates, standards for creating standards; all requiring consistency. Consistency across surrogates is an integral part of keeping categories within their limits so they do not overlap. Other cultures build their knowledge structures on overlapping concepts and structures. For instance, Chinese Taoist feng shui (already recognized in our global society for its marketability) seeks balance with two, yin and yang, four celestial animals, eight compass directions, five basic elements. Its fundamental thought was developed largely before the Christian era. Another group of examples are the many indigenous cultures that base their understanding of the universe on a circle rather than a hierarchy. In some of these cultures the relationships between entities are valued more than the entities themselves.

How can we expect that all cultures should shift to our way if they want to participate in international projects for better access. In our globalized world which is both bigger and smaller than it used to be there are oodles of language, cultural, and philosophical obstacles to information transfer. Technology can address some of these obstacles and theory offers different perceptions that allow us to question even fundamental tenets of our practice. By questioning fundamentals we can reveal unwarranted assumptions and change our practices accordingly.

\section{How do you trace the influence of feminism in knowledge organization today?}

Feminism offers strength to $\mathrm{KO}$ in two areas: conscientious representation and robust theory. We began with conscientious representation which focused on inclusion of topics related to women, changes to eliminate sexist language, and various aspects of classificatory structure (see Revolting Librarians,1972; Olson). Most of this practical work was applied in librarianship where it sometimes borrowed from the feminist movement to address equity issues such as pay equity, hiring and promotion, and other human resource concerns.

When I was in library school many educators mourned the low amount of theory in the LIS journals, newsletters, books. At conferences from ISKO to ALA to ASIST to the state and provincial library associations one heard similar lamentations. However as I 
had anticipated, there is plenty of information science theory and a small but active body of literature that uses feminist, poststructural, postcolonial and other theoretical writings from mid- to late $20^{\text {th }}$ century. These writings are closer to the humanities than to our other primarily empirical social and hard sciences research and question our hidden underlying presumptions. Feminist research often borrows research approaches across disciplines. As we increasingly join the multidisciplinary scholars of women's studies such research is being recognized as an asset.

As an example I will briefly describe how several feminist scholars currently influence my work. The first is Drucilla Cornell, a feminist legal scholar specializing in ethics. In her The Philosophy of the Limit (1992) Cornell asserts that all systems have limits. In a system there are those with power who maintain the status quo or make changes. Cornell, drawing on the work of Jacques Derrida and Emanuel Levinas, asserts that those of us within the system, have different types and amounts of power, but nevertheless we all have an infinite responsibility to the Other. Because systems have limits we cannot include everyone. What we can do is to make the limit permeable. For Cornell that means making space for excluded Others' voices to be heard -- if they want to be heard in that space.

Lorraine Code, a feminist philosopher, identifies spaces for voices to be heard as being Rhetorical Spaces (1995). The study of classification is full of spaces that are uncomfortable for some groups and topics. the space must allow for the topic to be taken seriously. Code's blatant example is trying to be taken seriously discussing abortion and choice in the Vatican. It is not likely to allow Other voices to be heard. In the same way classification takes entities out of their regular contexts and groups them into new structures - different contexts.

Well-known feminist African American author, Toni Morrison in her The Origin of Others addresses the category of race as a constructed concept. Those who had authority in the context of American slavery constructed and propagated slavery as a central institution. Slavery was no.t inevitable or even random. It was created and fostered methodically keeping one group in authority and an Other silenced.

Our systems are not irremediable. Because we know that categories and classes are constructed that we know that they can be restructured. They can be changed to make a system more permeable. We can combine, reprise, adapt, supplement, revise, annotate, translate, edit, update, annotate, control, define, index, represent, summarize, whatever. We already have techniques that can be applied to new issues while employing extant practices. For example, classified library catalogues have been largely abandoned in much of the world. In a classified catalog relevant items in a collection are assigned classification numbers to represent topics. The classification is indexed using one or more classification schemes. As a result, a collection about poodles can be organized for public use with a general scheme such as the DDC. It can be accessed by veterinarians, breeders, lay people who want to know about their pet. Switching languages and metathesauri are intellectually similar.

\section{REFERENCES}

CODE, Lorraine. Rhetorical Spaces: Essays from Gendered Locations. New York: Routledge, 1995.

CORNELL, Drucilla. The Philosophy of the Limit. New York: Routledge, 1992. 
Morrison, Toni. The origin of others: the Charles Eliot Norton Lectures. Cambridge: Harvard University Press, 2017.

OLSON, Hope A. Exclusivity, teleology and hierarchy: Our Aristotelean legacy. Knowledge Organization, v. 26, n. 2, p. 65-73, 1999.

OLSON, Hope A. How We Construct Subjects: A Feminist Analysis. Special issue on: Gender Issues in Information Needs and Services, eds. Cindy Ingold and Susan E. Searing. Library Trends, v. 56, n. 2, p. 509-541, 2007.

WEST, Celeste, Elizabeth Katz et al. (1972). Revolting librarians. San Francisco: Booklegger Press, 1972. 